\title{
Synsedimentary seismotectonic features in Triassic and Cretaceous sediments of the Intrasudetic Basin (U Devěti křížů locality) - regional implications
}

\author{
Jurand WOJEWODA ${ }^{1, *}$, Marta RAUCH ${ }^{1}$ and Aleksander KOWALSKI ${ }^{1}$ \\ 1 Wrocław University, Institute of Geological Sciences, PI. M. Borna 9, 50-204 Wrocław, Poland
}

Wojewoda, J., Rauch, M., Kowalski, A., 2016. Synsedimentary seismotectonic features in Triassic and Cretaceous sediments of the Intrasudetic Basin (U Devěti křížu locality) - regional implications. Geological Quarterly, 60 (2): 355-364, doi: 10.7306/gq.1279

Synsedimentary deformation structures have been recognized in Triassic and Cretaceous sedimentary rocks of the Trutnov Basin, which build a structural and morphological elevation between Červený Kostelec and Upice. Very well preserved sand injection and collapse structures, strike-slip shearings and listric faults occur in the "U Devěti kř́žů" Quarry. Their shapes and spatial distribution strongly correspond to local tectonic structures within the Intrasudetic Shear Zone (ISZ), especially to the faults which bound the rhomb-shaped depressions and elevations. All these structural sub-units compose the Intrasudetic Basin Suite (IBS). The soft-sediment deformations developed in the shallow subsurface and most likely resulted from the dominantly extensional and strike-slip kinematics within the ISZ.

Key words: Sudetes, Triassic, Cretaceous, injectites, collapse structures.

INTRODUCTION

Triassic and Cretaceous sedimentary rocks, described in this paper, crop out in the Sudetes Mountains within a relatively small area. They have been surveyed and described primarily on morphological or structural elevations. Accordingly, in the area of the Intrasudetic Synclinorium (IS) they are known from the region of the so-called Łączna Anticline (LA), which separates two structural depressions/brachysynclines - the Krzeszów (KB) and the Adršpach brachysynclines (AB; Cz. Adršpašska pánev). The strata are also known from the area of the Teplice Elevation (TE; vicinity of Bohdašín), which subdivides the Adršpach Brachysyncline from the Police Brachysyncline (PB; Cz. Polická pánev; Fig. 1). The sediments are also known from exposures and mine pits in the close vicinity of the Poríčí-Hronov Fault Zone (PHFZ), which marks the southern boundary of the Intrasudetic Synclinorium (e.g., Malé Svatoňovice locality; Wojewoda, 2007a, b, 2008a, b, 2009a, b, c). In turn, the best documented Triassic sediments occur on a morphological elevation that subdivides the Nachod and Trutnov basins (NB and TB, respectively). This area, located between Červený Kostelec and Úpice, is traditionally known as

\footnotetext{
* Corresponding author, e-mail: jurand.wojewoda@uwr.edu.pl
}

Received: November 10, 2015; accepted: February 2, 2016; first published online: February 18, 2016 the "U Devěti křížů" area (Fig. 2). Concurrently, the area represents a local structural depression - the Červený Kostelec Trough (CKT), which to the south-west prolongs into the Hronov Graben (HB; Fig. 2). The phenomena described below have been documented in the Krákorka Quarry, where quartz-kaolinitic sandstones are exploited, displaying a dense and regular parting jointing and bedding-parallel split surfaces.

The area described below is traditionally included by Czech geologists to the Trutnov Basin (cf. Holub, 1972; Uličný, 2004). This basin, together with the Mnichovo-Hradiště Basin (Cz. Mnichovohradiš ská pánev), comprise a superior regional structural-palaeogeographical unit - the Karkonosze Piedmont Basin (KPB; Cz. podkrkonošská pánev; cf. Tásler, 1961; Holub and Tásler, 1974). The Nachod Basin represents a separate structural unit with its own architecture and history (Wojewoda, 2007d; Burliga et al., 2008).

All the structural units and basins mentioned above occur within the Intrasudetic Shear Zone which represents one of the most important tectonic structures in the post-Variscan evolution of the Sudetes (Wojewoda, 2007c; Fig. 3). The northern boundary of the zone is the Poříćí-Hronov Fault Zone, a very distinct regional tectonic zone that bounds the Intrasudetic Synclinorium from the south (Wojewoda, 2008b, 2009b). The KPB and NB constitute together the Intrasudetic Basin Suite -a set of rhomb-shaped regional structural units. Both the sedimentary architecture of the basins and the structure of their boundaries and minor regional units occurring within them indicate that they mostly represent strike-slip and principally extensional phenomena typical of pull-apart basins (Wojewoda, 2007b, c, 2009a). 


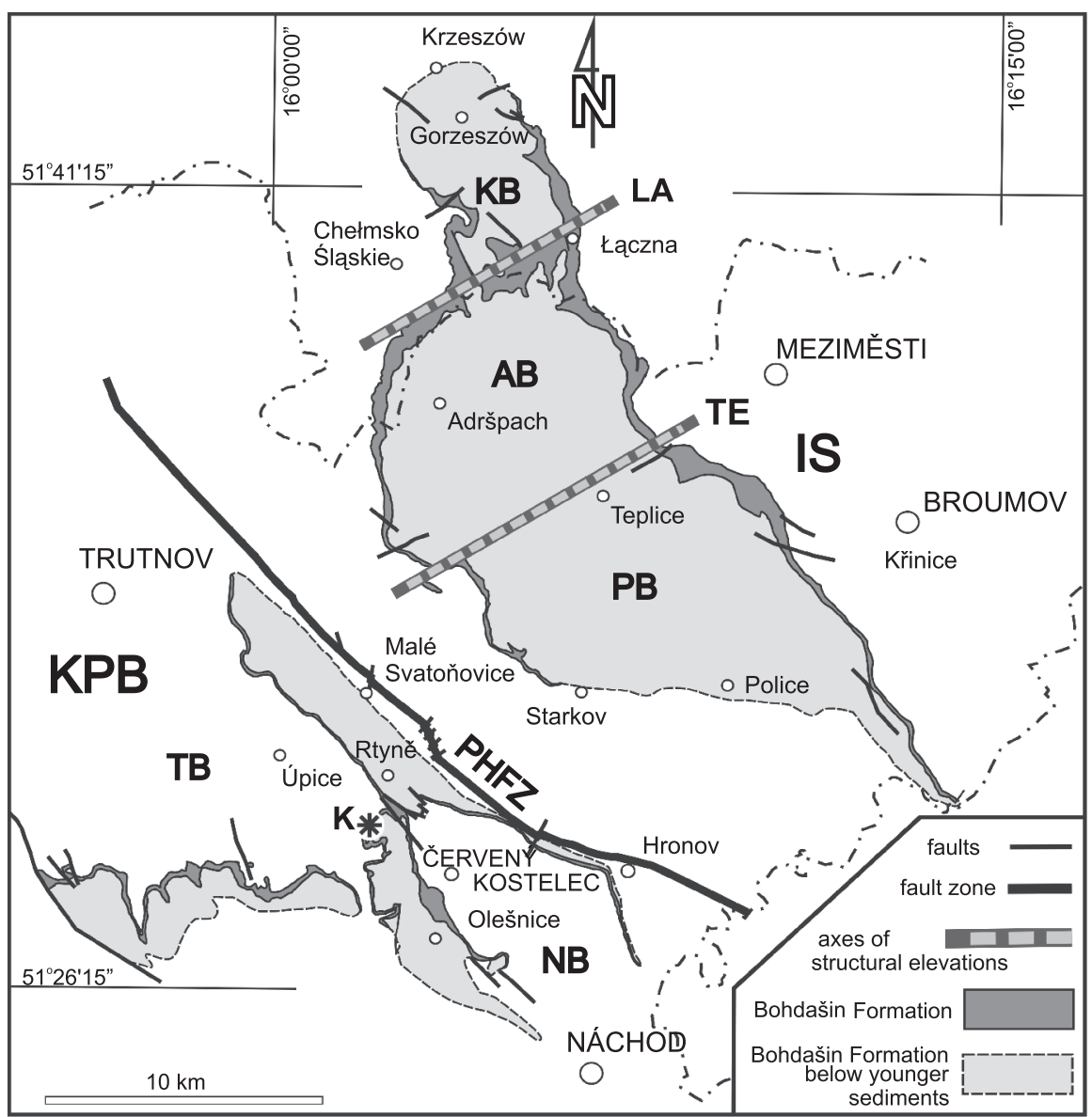

Fig. 1. Location of the Krákorka Quarry (K) with regard to the regional structural units and the extent of Trassic rocks in the area

$A B$ - Adršpach Brachysyncline, IS - Intrasudetic Synclinorium, KB - Krzeszów Brachysyncline, KPB - Karkonosze Piedmont Basin, LA - Łaczna Anticline, NB - Nachod Basin, PB - Police Brachysyncline, PHFZ - Poříčí-Hronov Fault Zone, TB - Trutnov Basin, TE - Teplice Elevation, axes of structural elevations based on: Jerzykiewicz (1971); Grocholski (1973); Don et al. (1981); Prouza et al. (1985), modified

\section{SANDSTONES FROM THE U DEVĚTI KŘIZŽO LOCALITY}

Permian, Triassic and Cretaceous formations are exposed in a relatively small area in the close vicinity and within a quarry, traditionally known as the Krákorka Quarry (Fig. 4). In the lower part of the quarry, beneath the mining level, occur the youngest continental sediments of the Permian succession in the Sudetes. They represent the Bohuslavice Formation and are classified as Thuringian in age (Holub, 1972). The Bohuslavice Formation consists of heterolithic, predominantly conglomeratic, lacustrine and fluvial sediments (e.g., Wojewoda and Mastalerz, 1989; Wojewoda, 2007c).

Triassic sediments, included in the Bohdašín Formation, discordantly or nearly concordantly, depending on the locality, overlie the Permian sediments. The Krákorka Quarry was established in the topmost part of the Bohdašín Formation. The lower and middle parts of the formation contain medium-grained, pinkish arkosic sandstones, which are interpreted as typical fluvial sediments (Prouza et al., 1985; Mroczkowski and Mader, 1985). Their thickness is up to $60 \mathrm{~m}$. The upper part of the Bohdašín Formation consists of quartz-kaolinite sand- stones with distinct and regular platy parting (Fig. 5A, B and G). Their occurrence is limited exclusively to the border zone between the Trutnov and Nachod basins (cf. Fig. 1). Because of the significantly different lithology of the lower and medium parts of the Bohdašín Formation, they were distinguished as a separate subunit - the Barchoviny Member (according to Holub, 1972). However, the informal name of these sediments - the Devět křižů sandstone (Holub, 1966) - is usually accepted and widely used in the literature. Worth mentioning is the fact that the boundary zone between the top of the Bohdašín Formation and the Devět křižů sandstone is not sharp and includes highly kaolinized coarse-grained sediments of undefined age (cf. Fig. 5B).

The uppermost part of the sedimentary succession of the Krákorka Quarry constitutes Upper Cretaceous marine clastic sediments assigned to the Peruc-Koryčany Formation and representing the Lower and Upper Cenomanian. Above them, in adjacent areas, e.g. in the Hronov Graben, occur fine-grained siliceous and calcareous deposits (mudstones) of the Bílá Hora Formation, which are included in the Lower Turonian (Tásler, 1966).

The structural distinction and uniqueness of the sedimentary rocks that crop out in the vicinity of Červený Kostelec and 

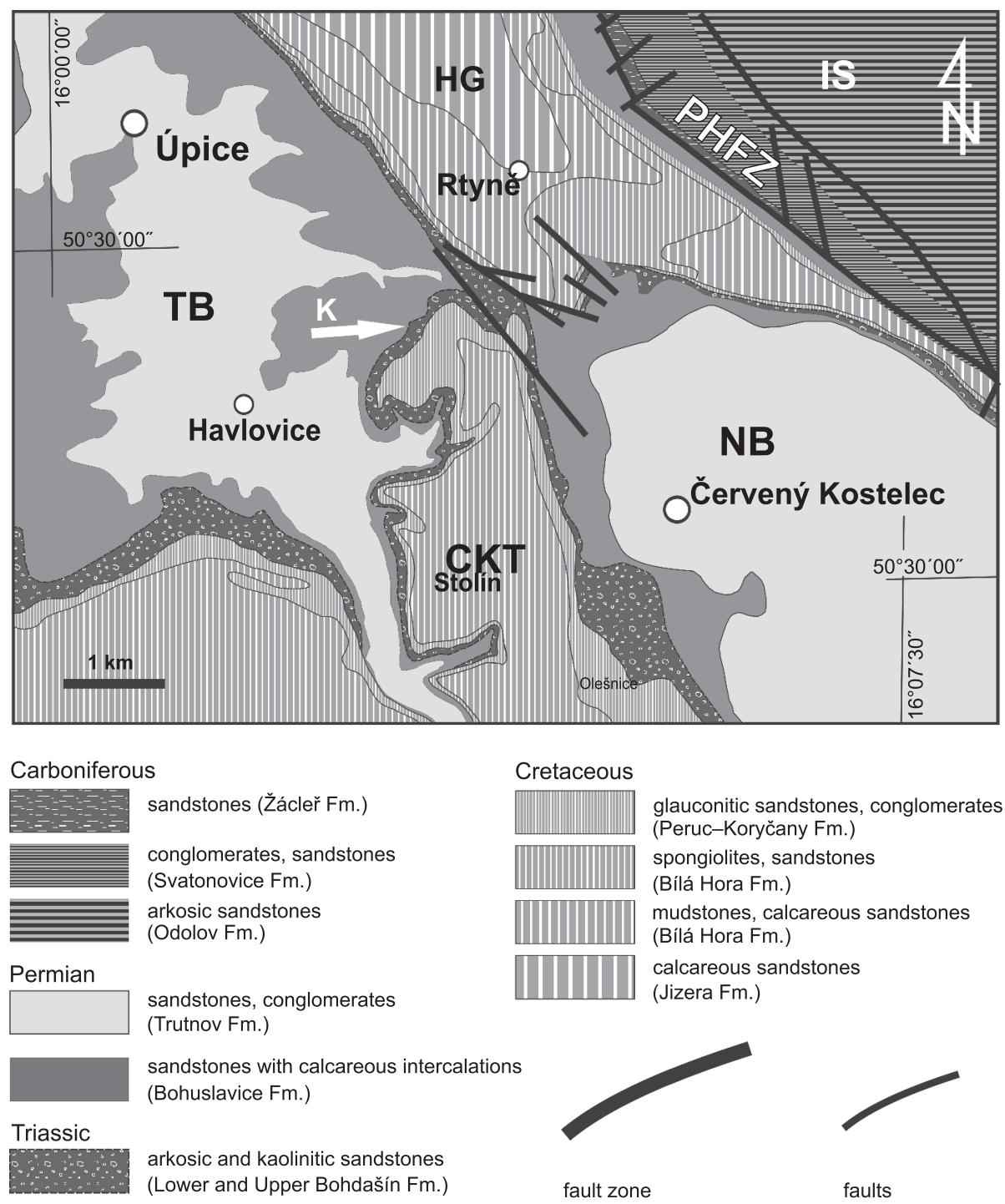

Fig. 2. Geological map of Červený Kostelec area

CKT - Červený Kostelec Trough, HG - Hronov Graben; faults based on Prouza (1988); for other explanations see Figure 1

Havlovice have already been noticed by Petrascheck (1933). $\mathrm{He}$ described them as "slab sandstones" (Ger. Plattensandsteine), occurring only in a narrow, forested strip known as the "nine crosses area" (Ger. Neunkreuzener), and included them to the Triassic. Petrascheck connected their occurrence in that particular locality with the margin of the Intrasudetic Synclinorium. According to him, rocks with a similar lithology, also kaolinized and assigned to the Lower Triassic variegated/multi-coloured sediments of the Buntsandstein, are exposed in the Chełmsko Ślaskie and Kochanów areas in the central-western part of the Intrasudetic Synclinorium. In papers and maps published earlier (e.g., Beyrich, 1854; Flegel, 1905), Triassic rocks have not been distinguished south of the Karkonosze Mountains, whereas the sediments described above were included in the Upper Permian (Müller, 1930). Despite that, Triassic Buntsandstein sediments were marked as a separate lithostratigraphic unit by Dathe et al. (1910) and Berg (1909) on the geological maps of the central part of the Intrasudetic Synclinorium.

In later publications, the stratigraphic position of the lower and middle part of the Bohdašín Formation did not change sig- nificantly (cf. Tásler, 1966; Holub, 1966; Prouza and Tásler, 1985) and by analogy to adjacent areas was interpreted as a sedimentary association typical of braided river and alluvial plain environments (Mroczkowski and Mader, 1985; Prouza and Tásler, 1985; Prouza et al., 1985).

Both the age and origin of the sandstones from the Krákorka Quarry remains controversial (see chronological review below). Valín (1964) interpreted the kaolinitic sandstones as lacustrine deposits. Holub (1972) expressed an opinion that they might represent shallow-marine, beach sediments. This viewpoint, however, was not supported in his later publications. Based on the change of colour, orientation of joints and occurrence of glauconite in the topmost parts of the quarry, Vejlupek (1983) suggested a Cretaceous age for the Devět křižů sandstones. Prouza et al. (1985) postulated shallow lake and/or alluvial plain sedimentary environments for the accumulation of these sediments. At the same time, he stated that the present position and distribution of the kaolinitic sandstones in relation to the lateral range of the entire Bohdašín Formation resulted from the migration of depocentres in the past. Based on findings of mud scrolls within the Devět křížů sediments, Mikuláš et al. (1991) suggested 

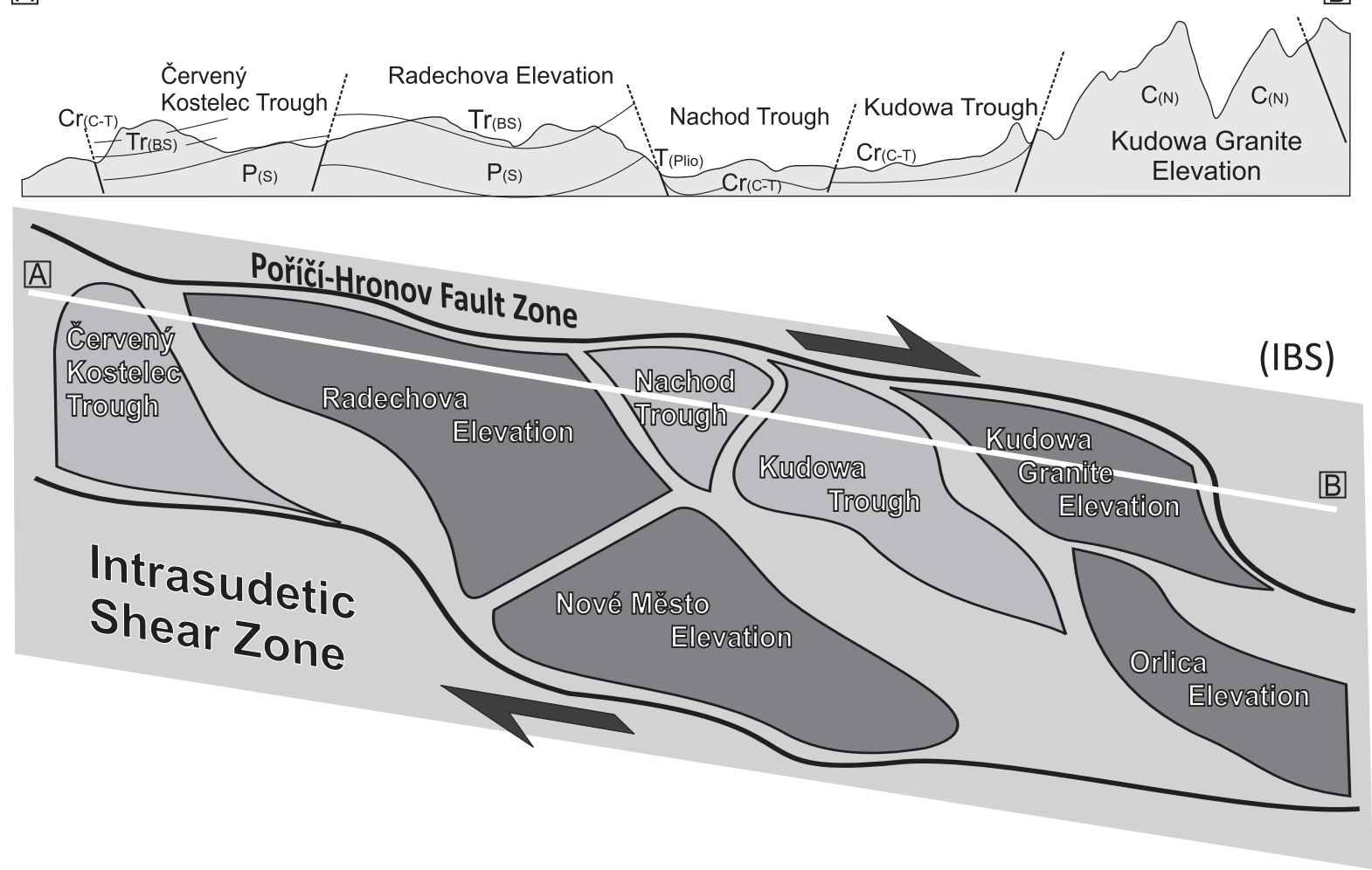

Fig. 3. Scheme of the Intrasudetic Basin Suite - a succession of structural depressions and elevations within the Intrasudetic Shear Zone (not to scale)

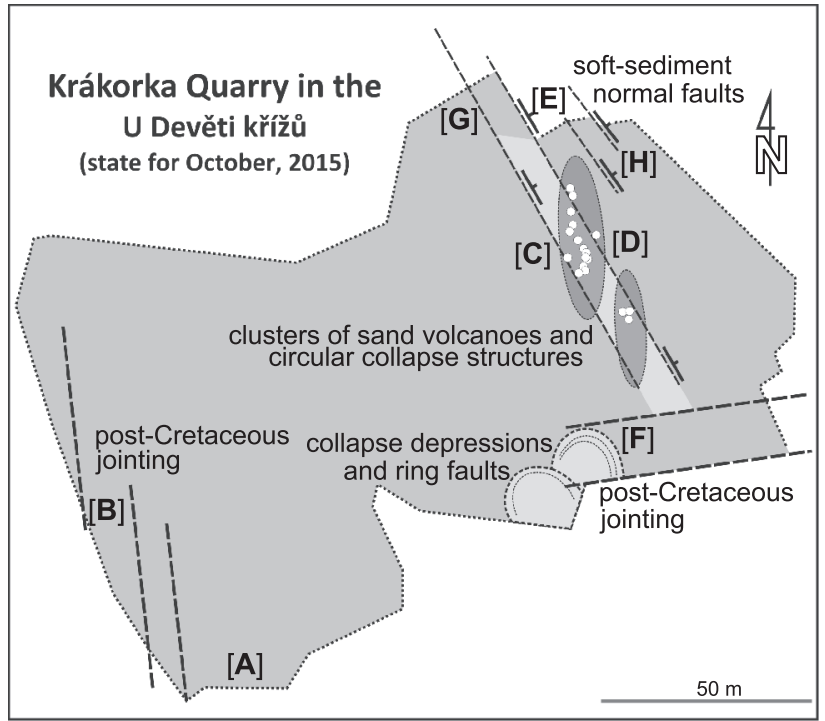

Fig. 4. Krákorka Quarry - spatial distribution of synsedimentary deformation structures and tectonic faults

A-H - locations of phenomena presented in Figure 5

the possibility of dry climate, and even aeolian conditions of their formation. The finding of a teropod footprint allowed Zajíc (1998) to propose a younger age for the entire Bohdašín Formation, especially for its topmost part. Structural and facies analysis of the sediments exposed in the Krákorka Quarry was conducted by Uličný (2004). By measuring the orientation of large-scale bedding and other sedimentary structures accompanying them, he confirmed that the Devěti křižů deposits were formed in an aeolian environment and record the Early Triassic climate changes in Central Europe.
In the Krákorka Quarry, the upper boundary of the sandstones of the Bohdašín Formation does not correspond to the base of the "transgressive glauconitic conglomerates" occurring in the upper part of the quarry. A subtle change in the degree of compaction, changes of colour from white to yellow-greenish of the sandstones exploited in the quarry, and the presence of glauconite, suggest the existence of discordance surfaces approximately $2 \mathrm{~m}$ below the conglomerate (traditionally called the "basal conglomerate"; Fig. 5A, B). This is also evidenced by biogenic structures, including trace fossils such as Thalassinoides and Arenicolites, and root casts, which indicate a shallow-marine, nearshore environment (cf. Mikuláš and Prouza, 1999; Uličný et al., 2009). These structures occur in the sandstones below a thin, up to $0.3 \mathrm{~m}$ thick conglomerate bed (Fig. $5 \mathrm{~B})$. Worth emphasizing is the fact that the time gap between the Devět křižů sandstones and the overlying Upper Cretaceous deposits is about $142 \mathrm{Ma}$.

The thickness of the kaolinitic sandstones occurring in the topmost part of the Bohdašín Formation reaches approximately $15 \mathrm{~m}$. The sandstones mined in the Krákorka Quarry in the $U$ Devěti křižů area reveal distinct regular, bedding-parallel splitting surfaces (platy parting), and vary from 7.5 to $9.5 \mathrm{~m}$ in thickness (see Uličný, 2004).

\section{SYNSEDIMENTARY DEFORMATION STRUCTURES}

Numerous phenomena, whose formation is most probably related to the tectonic and seismic activity during the sedimentation of Triassic and Cretaceous rocks, have been observed in the Krákorka Quarry and its immediate surroundings. The most spectacular phenomena are circular zones of sand liquefaction (Fig. 6). Earlier, such structures were described as sand volca- 

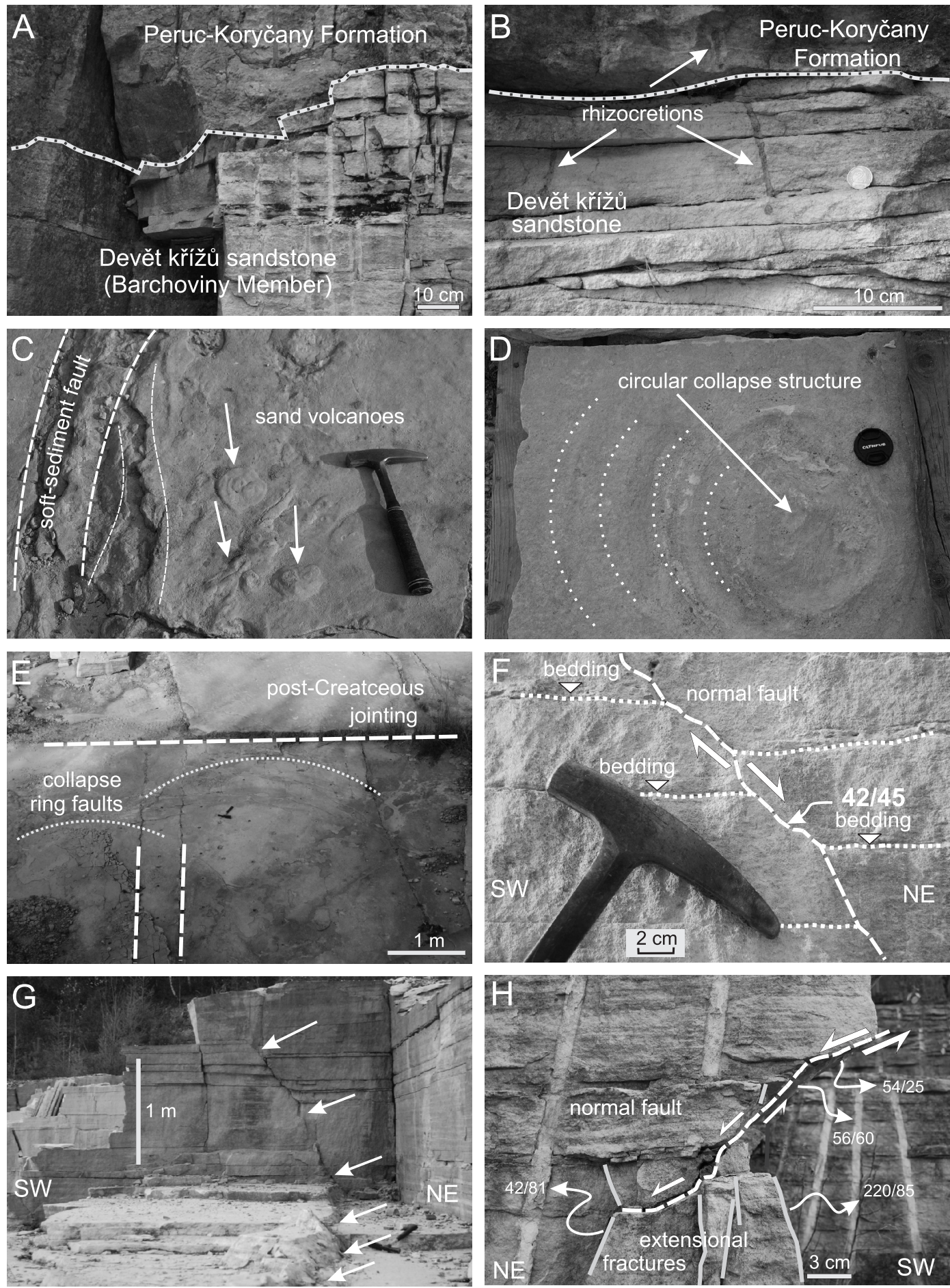

Fig. 5. Main sedimentary and tectonic features in the Krákorka Quarry

A, B - boundary between the Devět křižů sandstones and the Peruc-Koryčany Fm.; C - injection circular structures and soft-sediment faults; D - collapse circular structures; $\mathbf{E}$ - collapse depressions and ring faults; $\mathbf{F}-\mathbf{H}$ synsedimentary faults, zonally reactivated in the "tectonic" phase of deformation

noes (Uličný, 2004). A closer examination indicates an injection origin of some structures, although they are not typical sand volcanoes.

Injection circular structures occur on bedding planes, are irregular or circular, with a diameter from several centimetres to over $0.5 \mathrm{~m}$ and a thickness from 1 to $6 \mathrm{~cm}$. Their architecture resembles laccolites (Fig. 5C). The structures occur in fine- or me- dium-grained, very well sorted and laminated sand. Within the structures the sediment is massive and homogeneous. The sandy injection circular structures occur as isolated forms or as linearly distributed clusters, usually along zones interpreted as synsedimentary fissures (faults?) (Fig. 5C). The orientation of such clusters is exceptionally regular, almost ideally longitudinal (see Fig. 4). Neither planar nor pipe-like zones have been ob- 
served below the injection circular structures; if present, they would represent relicts of pathways along which concentrated flows of fluidized material appeared from beneath. Structures similar to those described above are known from sediments representing different ages and sedimentary environments (see compilations in Hurst et al., 2011; Van Loon and Maulik, 2011). Such phenomena are usually considered as seismic phenomena sensu lato. Some authors have indicated the relationship between injectites and synsedimentary faults (e.g., Carter and Norris, 1986; Vanneste et al., 1999; Neuwerth et al., 2006; Moretti and Sabato, 2007; Mazumder et al., 2009; Bonini, 2009). Analogous laccolite structures have been obtained in soil (sediment) fluidization modelling in conditions of cyclic overburden (shocks) (e.g., Rodrigues et al., 2009; Bureau et al., 2014).

Laccolite structures have been preserved probably due to the fact that the sediment surface was stabilized by microbial mats. This is evidenced by microbially induced sedimentary structures commonly occurring on bedding planes, sometimes referred to as "wrinkle structures" (Prave, 2002) or as "elephant skin" (Porada and Bouougri, 2007), and perfectly preserved desiccation (syneresis?) cracks, despite the complete lack of pelitic sediments within the sandstones (Fig. 6A, B). Similar as-
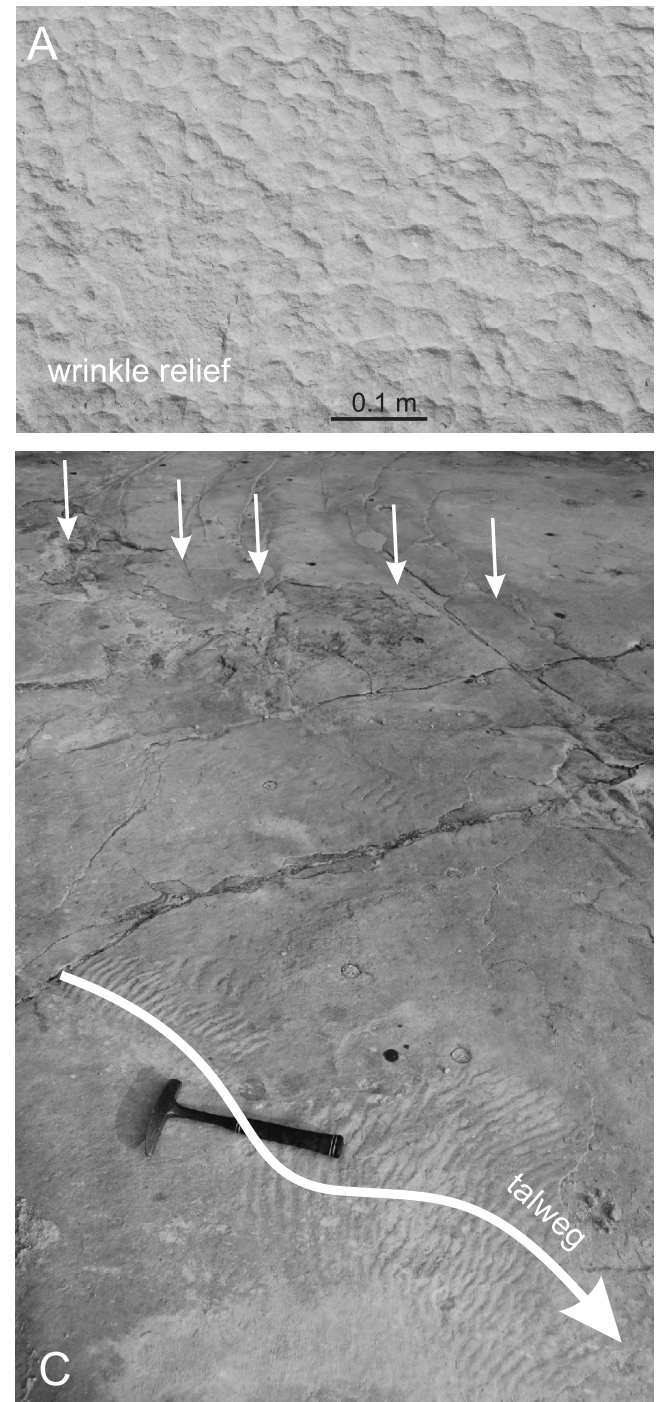

sociations of microbial mats and volcanoes are relatively common in shallow-marine peritidal environments (Taj et al., 2014). Although not always induced by seismic shocks, but for instance by the production of biogas in the sediment, most authors agree that the increase of pore pressure (e.g., due to wave swelling, rising tide, but also due to seismicity) is the main driving factor for the formation of sand volcanoes (Dornbos et al., 2007; Martin-Chivelet et al., 2011; Taj et al., 2014).

Collapse circular structures differ significantly from the previous structures. They do not represent three-dimensional structures (space, sediment), but deformations of the top surface of the sediment. Usually, the structures are a series of similarly shaped circular embankments (folds) with a wavelength from 3 to $7 \mathrm{~cm}$ and amplitude up to $1 \mathrm{~cm}$. A single structure is commonly composed of 3 to 5 rings, whose amplitudes gradually decrease outwards (cf. Fig. 5D). Some of the collapse structures from the Krákorka Quarry are extensional in character, i.e. they represent fragments of decollated beds, which form isolated "swimming pillows" on the fluidized sediment (see e.g., Moretti et al., 1999; Bureau et al., 2014).

Collapse depressions and ring faults occur in the southern part of the Krákorka Quarry (Figs. 4, 5E and 6C, D). The diame-
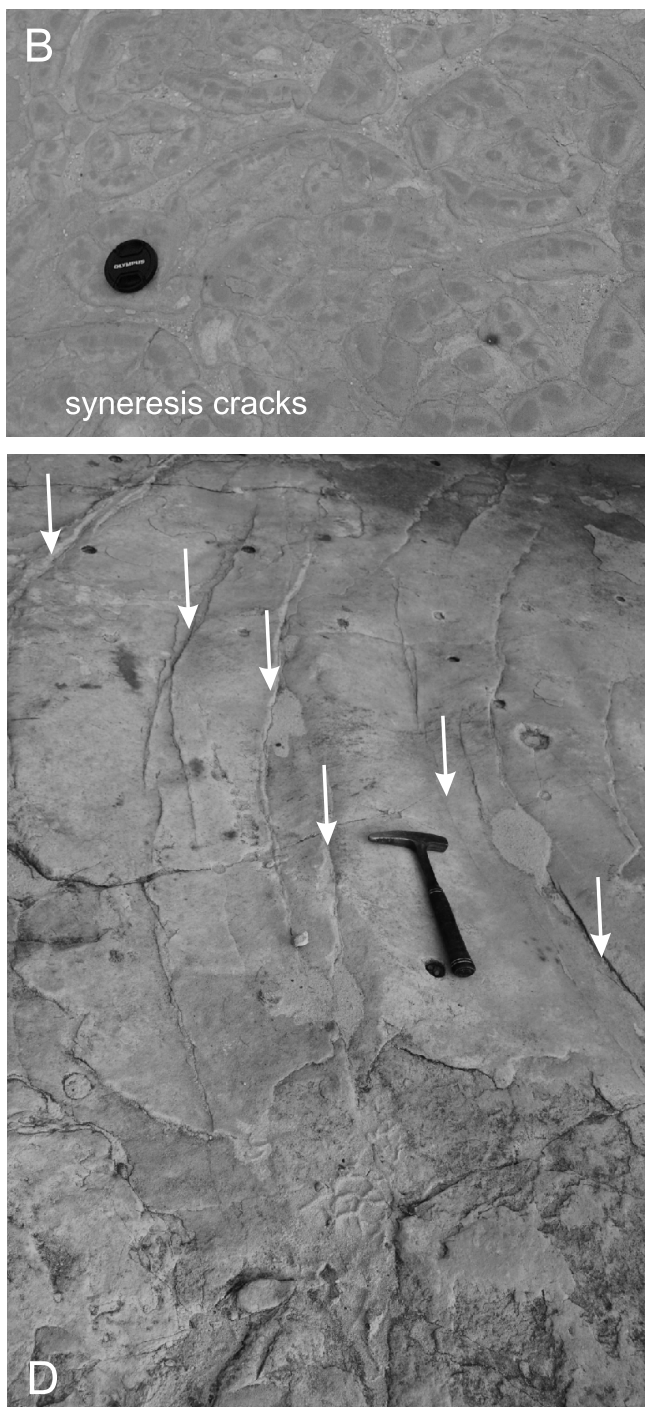

Fig. 6. Microbial reliefs (A, B) and collapse ring structures (C, D)

Note direction of water flow as simplified by long white arrow 
ters of the observed collapse depressions reach $5 \mathrm{~m}$. Subsequent structural steps within them decrease towards the southwest, which probably may indicate the palaeoslope gradient (Fig. 6C; see Audemard et al., 2005). The total depth of the structure visible in the Krákorka Quarry exceeds $25 \mathrm{~cm}$. Interestingly, fragments of the embankments have been washed out and form distinct pathways of water flow, perfectly documented by current ripple-marks (Fig. 6D). This means that the collapse took place in submarine conditions or forced the water to flow in a specific direction.

The spatial distribution of synsedimentary fissures, clastic injectites and collapse structures corresponds to the probable position of the palaeoslope, but is also distinctly related to the palaeogeographic position of the Devět krížů sandstones. Although the sandstones fill up a structural depression, they are marked in the present-day landscape as a distinct, NNW-SSE oriented morphological ridge. The orientation is recorded also by synsedimentary fissures and clastic laccolites within them. The latter structures occur as clusters with a slightly oblique orientation with regard to the fissure (fold) traces, which may suggest their dextral, strike-slip and extensional character. The possibilities of using the shape and spatial distribution of seismotectonic structures for this purpose has been evidenced by many authors (see review in: Bonini and Sani, 2000; Bonini, 2009; Hilbert-Wolf et al., 2009).

\section{FAULTS AND JOINTING}

In the Krákorka Quarry, normal faults, extensional fractures, and joints occur in the Devět křižủ sandstones. The oldest faults were most likely created in a fairly lithified or even unlithified sand deposit (cf. Fig. 5F-H). Displacements on the faults are not significant and do not exceed a few centimetres. The fault surfaces are usually non-planar, but consist of segments dipping at different angles. Some of the faults that most probably developed in the unlithified material, display a trend for the decrease of the dip angle at the floors of some beds. In some beds, the fault surface is parallel to the floor (Fig. $5 \mathrm{~F}-\mathrm{H}$ ). In such listric sections of normal faults, quartz fibrous mineralisation was observed on the surfaces of normal faults on the lowest quarry level (Fig. 7).

The sediment was also extended after lithification, and some of the earlier created normal faults were reactivated entirely or zonally (cf. Fig. 5F, H). Displacements from this phase of distortion/deformation are minimal (a few centimetres in range) and

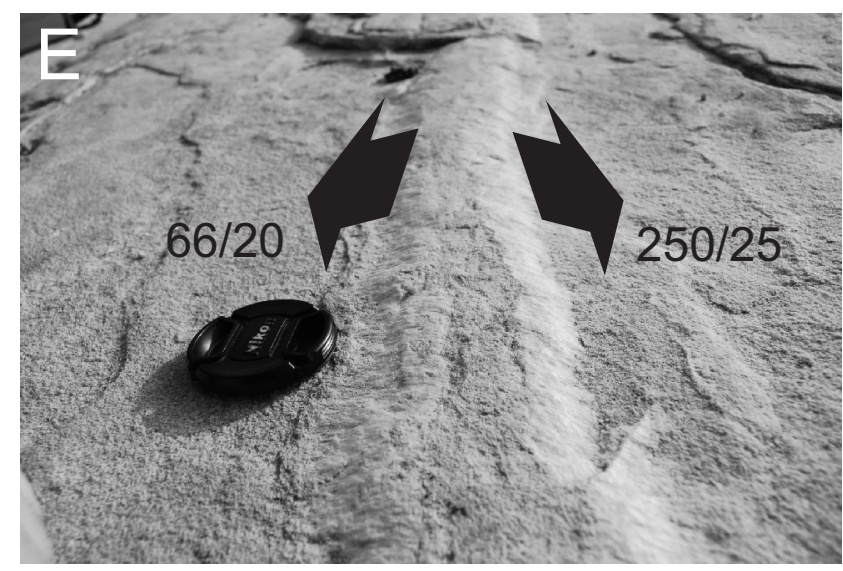

Fig. 7. Quartz fibrous mineralization on the surfaces of a "double-sided" normal listric fault accompanied by numerous, steep-dipping extensional fractures, cutting across the main fault surface (cf. Fig. 5F, H).

Both older and younger normal faults, surveyed in the eastern part of the quarry, have similar orientations and usually dip towards the north-east (cf. Figs. 5G, H and 7). Typically, the surfaces of the main normal faults, created in an unlithified deposit, dip toward the north-east, but in many places they are accompanied by smaller normal antithetic faults with opposite dip directions, toward the south-west (cf. Figs. 7 and 8). The dip of the surfaces of normal faults is usually in the range of 35-65, although the dominant dips of these normal faults are about $50^{\circ}$ (Fig. 8A). The dominant direction of the strike surfaces of the younger normal faults created after lithification is about NW-SE, rarely NNW-SSE (Fig. 8B). The dip of their surfaces is also variable, but usually close to $50^{\circ}$ (Fig. 8B).

The joint surfaces are almost vertical (Fig. 9A). Two joint sets dominate in the quarry, with strike surfaces oriented at close to the NW-SE and NE-SW (Fig. 9B). The orientation of these two joint sets indicates the presence of an orthogonal joint

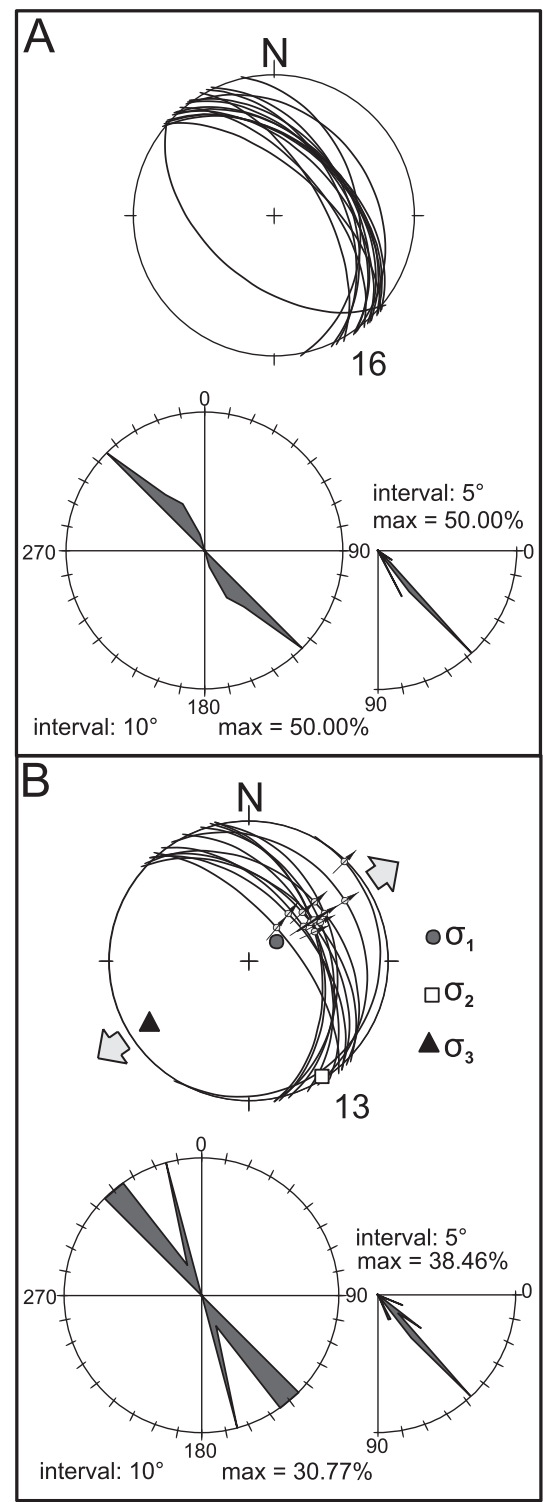

Fig. 8. Orientation of (A) pre-lithification normal faults, and later (B) post-lithification normal faults formed in a brittle regime, the arrows show the orientation of the extension (projection on the lower hemisphere and rose diagrams of the strike and dip angle of the normal fault surfaces) 

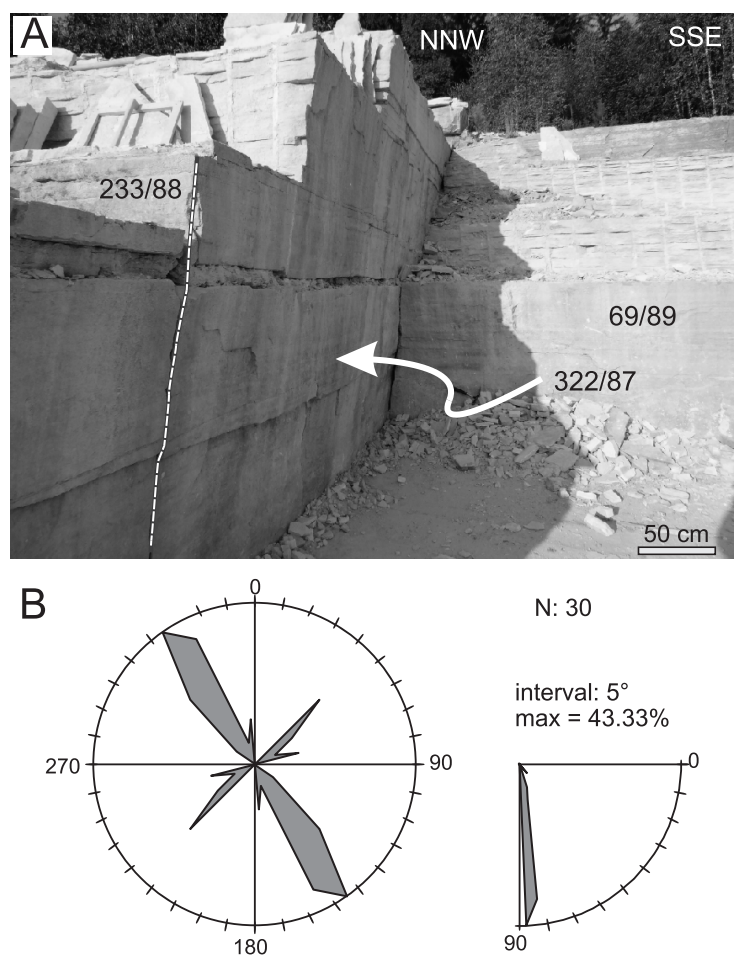

$\mathrm{N}: 30$

interval: $5^{\circ}$ $\max =43.33 \%$

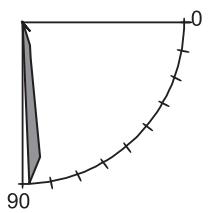

interval: $10^{\circ}$

$\max =23.33 \%$

Fig. 9. Joints in Triassic sandstones - (A) orthogonal joints,

(B) diagrams of the strike of the joint surfaces (left) and the dip angles of the joint surfaces (right)

system. Surfaces of this joint system cut the surfaces of older normal faults (cf. Fig. 5A, G). The strike directions of the orthogonal joint system are often almost parallel or perpendicular to the dominant strike direction of the younger normal faults (after lithification), which may suggest that the formation of both deformation systems in the Devět křižů sandstones could have been related to similarly oriented tension fields.

Vertically segmented normal faults are surfaces observed in different bedded rocks (Stewart and Hancock, 1991; Childs et al., 1996; Walsh et al., 2003). The normal faults of the oldest system of deformation in the above-described Triassic deposits from the U Devěti křižů locality are an example of segmented faults with contractional offsets. Normal faults solely with contractional offsets were described by Childs et al. (1996). Such vertically segmented faults may originate also from faults with surfaces dipping at a constant angle as a result of post-faulting compaction (see Wang, 1995).

\section{SUMMARY}

Quartz fibrous mineralisation on the "pre-lithification" fault surfaces was found exclusively on the lowest quarry level. Due to the low solubility of quartz it usually seldom fills subsurface fractures. However, it can be transported and precipitated subaerially in unlithified deposits; although the process is regarded to last for many tens of years (Maltman, 1994). The oldest normal faults have been created in a stress field with a NE-SW tension.

After lithification of the Devět křižů deposits, the sandstone beds were cut again by normal faults with features typical of a brittle regime. It seems that the orientation of the stress field did not change and these younger faults were also formed during NE-SW extension (azimuth N55 ${ }^{\circ}$ ). Therefore, some of the older faults were reactivated. Displacements along these faults were not significant, and the reactivation was usually accompanied by the development of almost vertical extensional fractures.

The Triassic sandstones are cut by two sets of joints, which form an orthogonal joint system. The first joint set with a $\mathrm{NW}-\mathrm{SE}$ orientation (azimuth $\mathrm{N} 47^{\circ}$ ) of the strike surface is a systematic joint, and the second joint set is NE-SW-oriented and orthogonal to the first joint set. Joint is an opening-mode fracture that develops in a direction perpendicular to the local orientation of the maximum tensile stress (see e.g., Hancock, 1985; Pollard and Aydin, 1988). Therefore, formation of an orthogonal cross joint requires rotation of the local stress field by about $90^{\circ}$. Rotation of the regional principal stress could have been caused by changes in fluctuations of regional stresses (Hancock et al., 1987). However, in this case, the orthogonal joint system has an orientation closely related to the orientation of normal faults (see Dunne and Hancock, 1994). The systematic joint has strike surfaces similarly oriented as the strike surfaces of normal faults, and the orthogonal cross joint is also perpendicular to the strike surface of normal faults. Such orientation of normal faults and joints may suggest the formation of an orthogonal joint system related to the development of younger normal faults in a brittle regime (see Kattenhorn et al., 2000).

The U Devěti křižủ area records a consequent structural development in similar geodynamic conditions from the Permian until present-day. Syntectonic terrestrial sedimentation commenced in the area in the Early Permian (Rotliegend, Autun),

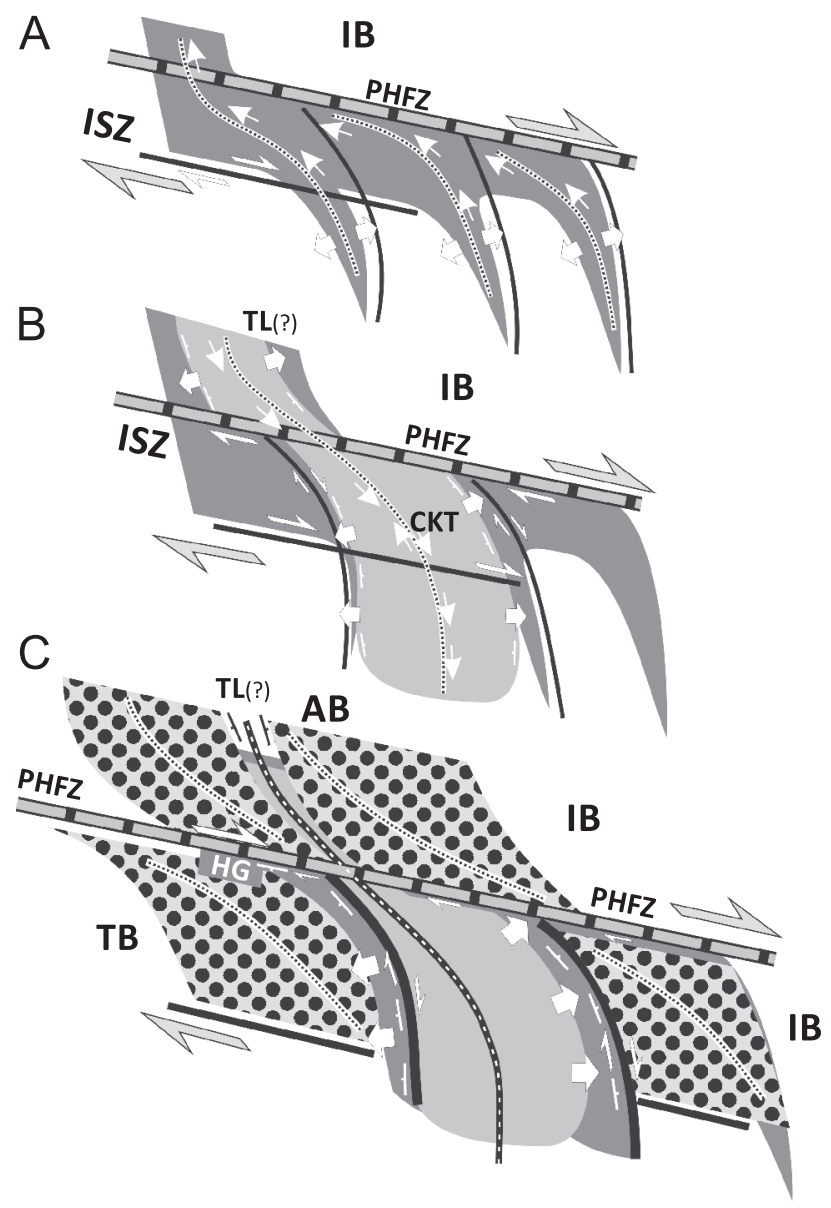

Fig. 10. Schematic evolution of the Červený Kostelec Trough and "U Devěti křižưŭ" elevation: Early Permian (A), Triassic (B) and post-Cretaceous (C)

Thick arrows show regional palaeokinematic trends, thin arrows indicate the regional palaeotransport of sedimentary material; for other explanations see Figures 1 and 2 
when an initial, rhomb-shaped pull-apart basin was formed in the Intrasudetic Shear Zone (Wojewoda 2007a, b, c; Fig. 10A).

The $U$ Devěti křižủ area is located almost centrally within a structure that was composed, at that time, of the present-day basin structures - the Trutnov and Nachod basins. This area was the basin depocentre in the Early Triassic (Upper Buntsandstein, Röt). The area formed a longitudinally elongated basin that represented land periodically flooded by the Röt Sea. The record of this interval points to terrestrial and shallow-marine sedimentation coupled with high tectonic and seismic activity (Fig. 10B). Due to the permanent meridional elongation of the basin, the area began its passive stage of development, becoming an elevation within the basin (first stage of inversion). At that time, meridional synsedimentary extension (synsedimentary listric faults) was particularly intense. The next stage is the Cretaceous transgression, during which the $U$
Devěti křižů area probably represented a distinct morphological elevation. This is evidenced, e.g. by a distinct erosional boundary between the Devět křižù sandstones and the Peruc-Koryčany Formation. Generations of jointing developed already during and after the formation of the Cretaceous cover. In the last stage, most probably during the Miocene, a subsequent inversion took place, and the Nachod and Trutnov basins became distinctly separated from each other by the U Devěti křižů morphological elevation (Fig. 10C). Listric faults were most probably formed in this interval; to a large degree they follow the fault traces or use older synsedimentary destruction zones.

Acknowledgements. We would like to thank the reviewers of this paper: P. Raczyński and one anonymous reviewer for their constructive comments. I would like to thank A. Żylińska for the linguistic improvement of the final version of this paper.

\section{REFERENCES}

Audemard, F.A., Gómez, J.C., Taverab, H.J., Orihuela, N., 2005 Soil liquefaction during the Arequipa Mw 8.4, June 23, 2001 earthquake, southern coastal Peru. Engineering Geology, 78 237-255.

Berg, G., 1909. Erläuterungen zur Geologischen Karte von Preußen und benachbarten Bundesstaaten. Liefferung 145, Blatt Schömberg. Preußischen Geologischen Landesanstalt, Berlin.

Beyrich, F., 1854. Über die Lagerung der Kreideformation im Schlesien. Abhandlungen Preußen Akademie der Wissenschaften, 26: 57-80.

Bonini, M., 2009. Mud volcano eruptions and earthquakes in the Northern Apennines and Sicily, Italy. Tectonophysics, 474: 723-735.

Bonini, M., Sani, F., 2000. Thrusting, strike-slip faulting and syntectonic deposition in the Potenza-Guardia Perticara Area (Basilicata, Southern Apennines, Italy). Memorie della Società Geologica Italiana, 55: 123-132.

Bureau, D., Mourgues, R., Cartwright, J., 2014. Use of a new artificial cohesive material for physical modelling: application to sandstone intrusions and associated fracture networks. Journal of Structural Geology, 66: 223-236.

Burliga, S., Martinek, K., Wojewoda, J., 2008. Perm karkonoskiego basenu piedmontowego i basenu Nachodu (in Polish). In: Baseny śródgórskie: kontekst regionalny środowisk i procesów sedymentacji (ed. J. Wojewoda): 64-110. Materiały Konferencyjne, wycieczka C WIND, Kudowa Zdrój, 15-21.09.2008.

Carter, R.M., Norris, R.J., 1986. Redeposited conglomerates in a Miocene flysch sequence at Blackmount, Western Southland, New Zealand. Sedimentary Geology, 18: 289-319.

Childs, C., Nicol, A., Watterson, J., Walsh, J.J., 1996. Fault overlap zones within developing normal fault systems. Journal of Structural Geology, 18: 1389-1397.

Dathe, E., Zimmermann, E., Berg, G., 1910. Erläuterungen zur Geologischen Karte von Preußen und benachbarten Bundesstaaten. Liefferung 145, Blatt Friedland. Preußischen Geologischen Landesanstalt, Berlin: 1-64.

Don, J., Jerzykiewicz, T., Teisseyre, A.K., Wojciechowska, I., 1981. Szczegółowa Mapa Geologiczna Sudetów 1:25 000, arkusz Lubawka (in Polish). Instytut Geologiczny, Warszawa.

Dornbos, S.Q., Noffke, N., Hagadorn, J.W., 2007. Mat-decay features. In: Atlas of Microbial Mat Features Preserved within the Clastic Rock Record (eds. J. Schieber, P.K. Bose, P.G. Eriksson, S. Banerjee, S. Sarkar, W. Altermann and O. Catuneau): 106-110. Elsevier, Amsterdam.
Dunne, W.M., Hancock, P.L., 1994. Palaeostress Analysis of Small-Scale Brittle Structures. Chapter 5. In: Continental Deformation (ed. P.L. Hancock): 101-120. Pergamon Press.

Flegel, K., 1905. Heuscheuer und Adersbach-Weckelsdorf. Eine Studie über die obere Kreide im böhmisch-schlesischen Gebirge (Dissertation): 1-36.

Grocholski, A., 1973. Szczegółowa Mapa Geologiczna Sudetów 1:25 000, arkusz Mieroszów (in Polish). Instytut Geologiczny, Warszawa.

Hancock, P.L., 1985. Brittle microstrutures: principles and practice. Journal of Structural Geology, 7: 437-457.

Hancock, P.L., Al Kadhi, A., Barka, A.A., Bevan, T.G., 1987. Aspects of analysing brittle structures. Annales Tectonicae, 1: $5-19$.

Hilbert-Wolf, H.L., Simpson, E.L., Simpson, W.S., Tindall, S.E., Wizevich, M.C., 2009. Insights into syndepositional fault movement in a foreland basin; trends in seismites of the Upper Cretaceous, Wahweap Formation, Kaiparowits Basin, Utah, USA. Basin Research, 21: 856-871.

Holub, V., 1966. Geologické Poměry Východního Podkrkonoší. Unpublished report (in Czech). Geofond ČR, Prague.

Holub, V., 1972. Permian of the Bohemian Massif. In: Rotliegend Essays on European Lower Permian (ed. H. Falke): 137-188. E. J. Brill (Holland).

Holub, V., Tásler, R., 1974. Mladší paleozoikum a spodní trias v podloží české krí́dové pánve (in Czech). In: Geologie české kř́dové pánve a jejího podloží (ed. M. Malkovský): 72-100. Ústřední Ústav Geologický, Praha.

Hurst, A., Scott, A., Vigorito, M., 2011. Physical characteristics of sand injectites. Earth-Science Reviews, 106: 215-246.

Jerzykiewicz, T., 1971. Cretaceous in the vicinity of Krzeszów (in Polish with English summary). Geologia Sudetica, 5: 281-327.

Kattenhorn, S.A., Aydin, A., Pollard, D.D., 2000. Joints at high angles to normal fault strike: an explanation using 3-D numerical models of fault-perturbed stress fields. Journal of Structural Geology, 22: 1-23.

Maltman, A., 1994. The Geological Deformation of Sediments. Chapman and Hall.

Martin-Chivelet, J., Palma, R.M., Lopez-Gomez, J., Kietzmann, D.A., 2011. Earthquake-induced soft-sediment deformation structures in Upper Jurassic open-marine microbialites (Neuquen Basin, Argentina). Sedimentary Geology, 235: 210-221.

Mazumder, R., Rodríguez-López, J.P., Arima, M., Van Loon, A.J., 2009. Palaeoproterozoic seismites (fine-grained facies of the Chaibasa Fm., E India) and their soft-sediment deformation 
structures. Geological Society Special Publications, 323: 301-318.

Mikuláš, R., Prouza, V., 1999. The Cretaceous biogenic structures created in Triassic sandstones (Devět křížů at Červený Kostelec, NE Bohemia, Czech Republic). Véstník Českého Geologického Ústavu, 74: 335-342.

Mikuláš, R., Plička, M., Skalický, J., 1991. A find of mud scrolls in Lower Triassic sandstone at the locality Devět křižů (NE Bohemia). Véstník Českého Geologického Ústavu, 66: 247-249.

Moretti, M., Sabato, L., 2007. Recognition of trigger mechanisms for soft-sediment deformation in the Pleistocene lacustrine deposits of the Sant'Arcangelo Basin (Southern Italy): seismic shock vs. overloading. Sedimentary Geology, 196: 31-45.

Moretti, M., Alfaro, P., Caselles, O., Canas, J.A., 1999. Modelling seismites with a digital shaking table. Tectonophysics, 304: 369-383.

Mroczkowski, J., Mader, D., 1985. Sandy inland braidplain deposition with local aeolian sedimentation in the lower and middle parts of the Buntsandstein and sandy coastal braidplain deposition in the topmost Zechstein in the Sudetes (Lower Silesia, Poland). Lecture Notes in Earth Sciences, 4: 165-195.

Müller, G., 1930. Der kontinentale Zechstein im Süden des Riesengebirges. Abhandlungen der Preußischen Geologischen Landesanstalt, N.F., Berlin, 130: 1-90.

Neuwerth, R., Suter, F., Guzman, C.A., Gorin, G.E., 2006 Soft-sediment deformation in a tectonically active area: the Plio-Pleistocene Zarzal Formation in the Cauca Valley (Western Colombia). Sedimentary Geology, 198: 67-88.

Petrascheck, W., 1933. Der böhmische Anteil der Mittelsudeten und sein Vorland. Mitteilungen der Geologischen Gesellschaft in Wien, 26: 1-136.

Pollard, D.D., Aydin, A., 1988. Progress in understanding jointing over the past century. GSA Bulletin, 100: 1181-1204.

Porada, H., Bouougri, E., 2007. "Wrinkle structures" - a critical review. In: Atlas of Microbial Mat Features Preserved within the Clastic Rock Record (eds. J. Schieber, P.K. Bose, P.G. Eriksson, S. Banerjee, S. Sarkar, W. Altermann and O. Catuneau): 135-144. Elsevier, Amsterdam.

Prave, A.R., 2002. Life on land in the Proterozoic: evidence from the Torridonian rocks of northwest Scotland. Geology, 30: 811-814.

Prouza, V., 1988. Geologická Mapa ČSR (in Czech). List 04-32 Broumov, 1:50 000. Ústřední Ústav Geologický, Praha.

Prouza, V., Tásler, R., 1985. Přehledná geologická mapa podkrkonošské pánve (in Czech). Ústřední Ústav Geologický, Praha.

Prouza, V., Tásler, R., Valín, F., Holub, V., 1985. Gravelly to sandy braidplain deposition in the Buntsandstein-facies Bohdašín Formation in Northeastern Bohemia (Czechoslovakia). Lecture Notes in Earth Sciences, 4: 397-410.

Rodrigues, N., Cobbold, P.R., Lrseth, H., 2009. Physical modelling of sand injectites. Tectonophysics, 474: 610-632.

Stewart, S.A., Hancock, P., 1991. Scales of structural heterogeneity with neotectonic normal fault zones in the Aegean region. Journal of Structural Geology, 13: 191-204.

Taj, R.J., Aref, M.A.M., Schreiber, B.C., 2014. The influence of microbial mats on the formation of sand volcanoes and mounds in the Red Sea coastal plain, south Jeddah, Saudi Arabia. Sedimentary Geology, 311: 60-74.

Tásler, R., 1961. Prehled geologie permokarbonu a spodniho triasu (in Czech). In: Vysvetlivky k prehledne geolicke mape CSSR (eds. J. Svoboda and J. Chaloupsky). Ústřední Ústav Geologický, Praha.

Tásler, R., 1966. Triassic. In: Regional Geology of Czechoslovakia, part I: the Bohemian Massif (eds. J. Svoboda et al.): 481-483. Publishing House of the Czechoslovakia Academy of Sciences, Prague.

Uličný, D., 2004. A drying-upward aeolian system of the Bohdašín Formation (Early Triassic), Sudetes of NE Czech Republic: re- cord of seasonality and long-term palaeoclimate change. Sedimentary Geology, 167: 17-39.

Uličný, D., Špičáková, L., Grygar, R., Svobodová, M., Čech, S., Laurin, J., 2009. Palaeodrainage systems at the basal unconformity of the Bohemian Cretaceous Basin: roles of inherited fault systems and basement lithology during the onset of basin filling. Bulletin of Geosciences, 84: 577-610.

Valín, F., 1964. Litologie triasu v severovýchodních Čechách (in Czech). Véstník Českého Geologického Ústavu, 39: 459-462.

Van Loon, A.J., Maulik, P., 2011. Abraded sand volcanoes as a tool for recognizing paleo-earthquakes, with examples from the Cisuralian Talchir Formation near Angul (Orissa, eastern India). Sedimentary Geology, 238: 145-155.

Vanneste, K., Meghraoui, M., Camelbeeck, T., 1999. Late Quaternary earthquake-related soft-sediment deformation along the Belgian portion of the Feldbiss Fault, Lower Rhine Graben system. Tectonophysics, 309: 57-79.

Vejlupek, M., 1983. Ke stratigrafické pozici devítikřížských pískovců (in Czech). Véstník Českého Geologického Ústavu, 58: 57-59.

Walsh, J.J., Bailey, W.R., Childs, C., Nicol, A., Bonson, C.G., 2003. Formation of segmented normal faults: 3-D perspective. Journal of Structural Geology, 25: 1251-1262.

Wang, X., 1995. Estimation of the variation in apparent displacement along normal fault traces refracted by differential compaction. Journal of Structural Geology, 17: 191-204.

Wojewoda, J., 2007a. Palaeogeography and tectonic evolution of the Žernov-Nachod-Kudowa sedimentary area. In: 5th Meeting of the Central European Tectonic Studies Group (CETEG'5), April 11-14.04.2007, Tepla.

Wojewoda, J., 2007b. Žd'árky-Pstrążna Dome - dextral strike-slip fault-related structure at the eastern termination of the Pořiči-Hronov Fault Zone (Sudetes, Góry Stołowe Mts.). In: 5th Meeting of the Central European Tectonic Studies Group (CETEG'5), April 11-14.04.2007, Tepla

Wojewoda, J., 2007c. Neotectonic aspect of the Intrasudetic Shear Zone. Acta Geodynamica et Geomaterialia, 4: 1-11.

Wojewoda, J., 2007d. Perm basenu Nachodu. Sedimentologica, 1: 85-99.

Wojewoda, J., 2008a. Post-Variscan evolution of the Poříčí-Hronov zone. 9th Czech-Polish Workshop on Recent Geodynamics of the Sudeten and Adjacent Areas, 12-15.11.2008, Náchod, Astracts: $27-28$

Wojewoda, J., 2008b. Poříćí-Hronov strike-slip zone related structures. 9th Czech-Polish Workshop on Recent Geodynamics of the Sudeten and Adjacent Areas, 12-15.11.2008, Náchod, Astracts: $29-30$

Wojewoda, J., 2009a. Žd'arky-Pstrażna Dome: a strike-slip fault-related structure at the eastern termination of the Poríčí-Hronov Fault Zone (Sudetes). Acta Geodynamica et Geomaterialia, 6: 273-290.

Wojewoda, J., 2009b. The role of the Pořićí-Hronov Fault Zone in foundation of sudetic basins. In: 7th Meeting of the Central European Tectonic Studies Group (CETEG'7), 13-16.05.2009, Pecs. Abstracts.

Wojewoda, J., 2009c. Poříčí-Hronov Fault Zone: Malé Svatoňovice. 10th Czech-Polish Workshop on Recent Geodynamics of the Sudeten and Adjacent Areas, 5-7.11.2009, Szklarska Poręba, Poland

Wojewoda, J., Mastalerz, K., 1989. Climate evolution and allo- and autocyclic sedimentation of Upper Carboniferous and Permian continental deposits in the Sudetes (in Polish with English summary). Przegląd Geologiczny, 37: 173-180.

Zajíc, J., 1998. The first find of the dinosaurian footprint in the Czech Republic (the Krkonoše Piedmont Basin) and its stratigraphic significance. Journal of the Czech Geological Society, 43: 273-275. 